\title{
ANALISIS ELEMEN VISUAL VIDEO EDUKASI NEUROPLASTISITAS
}

\author{
Denis Oktavianto $^{1)}$, Dendi Pratama ${ }^{2)}$, Santi Sidhartani ${ }^{3)}$ \\ Program Studi Desain Komunikasi Visual, \\ Fakultas Bahasa dan Seni, Universitas Indraprasta PGRI, \\ Jl. Nangka No. 58 C, Tanjung Barat, Jakarta 12530, Indonesia,
}

Denisokt12@gmail.com

\begin{abstract}
Abstrak
Neuroplastisitas adalah kemampuan yang dimiliki oleh otak semua manusia. Begitu sempurnannya otak diciptakan oleh sang pencipta dengan berbagai fungsinya, salah satunya adalah neuroplastistas. Dengan adanya neuroplastistas, otak dapat memperbaharui sel, bisa memilih sel neuron yang sudah tidak dianggap tidak terlalu beguna dan menghilangkannya. Banyaknya kegunaan neuroplastisitas ini mendorong banyak pihak untuk membuat video edukasi tentang neuroplastisitas. Salah satu video tersebut tersedia pada platform digital youtube dalam channel bernama Sentis. Penelitian ini bertujuan untuk menganalisis elemen visual yang digunakan dalam video tersebut. Metode penelitian yang dipakai adalah metode penelitian kualitatif. Data dikumpulkan dengan studi literatur, observasi dan wawancara dengan narasumber terkait. Hasil penelitan ini menunjukkan bahwa video edukasi tersebut memiliki konsep dan elemen visual yang detail. Pemilihan warna, tipografi, dan ilustrasi sangat dipertimbangkan, sehingga sesuai dengan tingkat pemahaman target audiens.
\end{abstract}

Kata Kunci: Neuroplastisitas, Video Edukasi, Elemen Visual.

\begin{abstract}
Neuroplasticity is a capacity that is owned by the brain of all humans, once the brain is perfected by the creator with various functions, neuroplasticity is one of them, can renew cells, can select neuron cells that are no longer considered useless and eliminate them. From the many important uses of neuroplasticity, an educational video about neuroplasticity was created on a platform called YouTube with channel sentis. The research method used is qualitative research methods. This method examines objects and media by studying literature, observations and sources in this way the researcher examines the video. And the results of the research show that the educational video pays close attention to making it by using visual elements. Become easier to understand and very good at applying visual elements.
\end{abstract}

Keywords: Neuroplasticity, educational videos, visuall elemens.

Correspondence author: Denis Oktavianto, Denisokt12@gmail.com, Jakarta, and Indonesia

This work is licensed under a $C C-B Y-N C$ 


\section{PENDAHULUAN}

Otak ialah aset berharga yang dimiliki setiap manusia. Otak berperan penting terhadap diri dan masa depan seseorang. Otak bisa mengendalikan semua apabila bekerja dengan baik. Otak memiliki keistimewaan yaitu neuroplastisitas, yang dapat memperbaharui sel sel yang sudah rusak, bahkan bisa merubah masa depan seseorang.

Otak manusia mengendalikan semua, termasuk rasa emosional yang ada di dalam tubuh. Bambang Iman Santoso mengatakan bahwa otak manusia mampu memproduksi segalanya dari pengalaman meditatif transendental yang mendalam. Dipicu menjadi sedikit bingung, muncul rasa takut dan depresi kemarahan yang tidak masuk akal.

Otak memiliki keistimewaan yaitu neuroplastisitas, kemampuan untuk memperbaharui sel sel yang sudah rusak, bahkan bisa merubah masa depan seseorang. Bambang Iman Santoso mengatakan bahwa neuroplastisitas memiliki kemampuan untuk mengubah otak manusia. Anggap saja otak manusia sedang memproses data yang tidak terhitung banyak jumlahnya, namun manusia hanya menyadari sebagian kecil dari proses tersebut.

Otak memiliki sifat netral, apapun yang dipikirkan atau dilakukan, itulah yang akan dianggap pemikiran dan pola pikir. Ketika manusia memikirkan hal-hal negatif, maka otak akan memiliki pikiran negatif, maupun sebaliknya. Jadi manusia bisa memilih dan membentuk apa yang mau diberikan kepada otak. Wattimena (2015: 2) mengemukakan bahwa hasil penelitian neuroplastisitas amat penting untuk hidup manusia, karena memberi harapan nyata, bahwa hidup bisa berubah. Krisis tidak selamanya bertahan. Luka dan sakit bisa disembuhkan, asal mau bekerja keras. Nasihat-nasihat semacam ini sekarang bukan sekedar himbauan belaka, tetapi didukung oleh ratusan hasil penelitian yang dilakukan oleh berbagai ilmuwan bermutu di seluruh dunia.

Sujana (2018: 3) mengemukakan bahwa sekitar 120 tahun yang lalu, William James menjadi orang pertama yang mengemukakan teori neuroplastisitas. Teori tersebut tertulis dalam karyanya yang berjudul Principles of Psycology. Ia mengemukakan bahwa otak manusia dapat terus menerus mengalami perubahan fungsional. Seorang ahli saraf berkebangsaan Polandia, Jerzy Konorski adalah yang pertama menggunakan istilah "neuroplastisitas" pada tahun 1948. Konorski (dalam Sujana, 2018: 3) mengemukakan sebuah teori bahwa neuron yang diaktivasi oleh kedekatannya dengan sirkuit saraf yang aktif, akan berubah dan menggabungkan dirinya ke dalam sirkuit tersebut. Hebb (dalam Sujana, 2018: 3) mengemukakan bahwa perubahan proses biokimia pada satu neuron dapat menstimulasi aktivasi sinaps-sinaps di sekitarnya. Hal ini merupakan prinsip dasar plastisitas sinaptik. Paul Bach-yRita adalah yang pertama mendemonstrasikan neuroplastisitas pada kasus nyata. Rita (dalam sujana, 2018: 3) mengatakan bahwa bagian otak yang sehat dapat mengambil alih fungsi bagian otak yang mengalami cedera. Hal ini menjadi dasar dari terapinya untuk pasien-pasien yang mengalami kerusakan vestibular. Taub (dalam Sujana, 2018:3) mengatakan bahwa dia telah membuktikan pertama dengan percobaan terhadap kera rhesus lalu pada manusia bahwa dengan mengikat separuh bagian tubuh yang sehat pada kasus hemiplegia akan "memaksa" bagian otak yang rusak untuk mempercepat proses rehabilitasi.

Neuroplastisitas ini sudah banyak diteliti untuk membantu manusia agar bisa mendapatkan perubahan pada hidup, perilaku, cara berpikir, dan kerja otaknya. Merzenich (dalam Sujana, 2018:3) mengemukakan bahwa dia telah merancang sebuah perangkat lunak untuk membantu orang-orang dengan kesulitan belajar. Neuroplastisitas adalah hal yang menandai Dekade otak yaitu antara tahun 1990- 2000, di mana Presiden Amerika George H.W Bush mencoba meningkatkan kesadaran masyarakat akan manfaat yang dihasilkan oleh penelitian mengenai otak (Sujana, 2018: 3).

Neuroplastisitas ini memiliki peranan penting sebab dapat memulihkan organ otak yang bermasalah, seperti dalam masalah ganguan jiwa. Neuroplastisitas inilah yang berperan untuk membuat otak bisa menjadi normal kembali dan membuat seseorang memiliki harapan untuk masa depan yang lebih baik. Kembaren (2018: 1) mengemukakan bahwa neuroplastisitas ini bisa meningkatkan kesadaran pada masyarakat bahwa otak memang memegang peranan penting dalam semua aspek hidup 
manusia. Otak memiliki ketahanan dan dapat dilatih. Ini bermanfaat bagi orang yang bekerja di ranah kesehatan jiwa karena kondisi jiwa sesungguhnya adalah kondisi otak. Bagi orang dengan gangguan jiwa, ini adalah suatu harapan untuk dapat pulih dan kembali berfungsi serta produktif.

Dengan mengetahui cara kerja neuroplastisitas ini, setiap orang yang mengalami kerusakan otak, mengalami frustasi, merasa gagal dalam kehidupannya akan bisa bangkit, bisa merubah masa depannya. Perubahan ke arah yang lebih baik itu dapat terjadi karena setiap manusia memiliki neuroplastisitas di dalam otaknya. Wattimena (2015: 2) mengemukakan bahwa semua orang bisa merubah pola pikirnya, semua orang bisa bangkit dari keterpurukan, semua orang layak memiliki masa depan yang lebih baik. Akan tetapi itu semua harus diraih dengan kerja keras dan keinginan tinggi untuk berubah.

Kania dkk. (2017: 42) mengemukakan bahwa plastisitas otak atau neuroplastisitas adalah kapasitas yang melekat pada jaringan saraf untuk membentuk koneksi atau sinapsis interneuronal baru (sinaptogenesis) atau mengganti yang tidak berguna, tidak berfungsi (degenerasi saraf) neuron di otak dengan neuron baru (neurogenesis). Plastisitas sinaptik adalah kemampuan untuk mengubah kekuatan sinaptik. Perubahan kekuatan termasuk neurotransmiter. Neuroplastisitas terdiri dari dasar neurokimia yang penting dalam pembelajaran dan memori. Efek neuroplastisitas adalah menata ulang fungsi neuron untuk memungkinkan adaptasi dan perbaikan diri yang cepat, yang dapat diterjemahkan ke dalam proses pembelajaran dan memori di semua tingkat sistem saraf. Ini juga terdiri dari rangsangan intrinsik dari neuron dengan pengaruh pada penyimpanan informasi. Neuroplastisitas berperan untuk membentuk pola pikir, membentuk karakter, membentuk masa depan seseorang. Otak manusia dewasa dianggap sebagai sebuah struktur organ yang terbentuk selama masa perkembangan dan kemudian menjadi kaku saat dewasa. Perubahan pada otak yang diterima dahulu hanyalah sebatas pada proses belajar dan memori. Namun, faktanya otak ternyata mengalami perubahan yang berkelanjutan sepanjang masa hidup dan hal ini merupakan salah satu penemuan terpenting dalam ilmu neuroscience modern. Perubahan yang terjadi di otak ini dikenal dalam sebuah istilah umum sebagai neuroplastisitas, yang meliputi neurogenesis, plastisitas sinaps, dan synaptogenesis. (Chostandy dan Moheb dalam Andreas, 2013: 132-135).

Selain itu neuroplastisitas ini memiliki kemampuan untuk membuat seseorang beradaptasi terhadap lingkungan, mengenal bahaya, membuat stimulus stimulus yang akan membuat kepekaan terhadap suatu kondisi. Malhotra (dalam Kania dkk, 2017: 42) mengemukakan bahwa neuroplastisitas adalah kemampuan otak untuk membentuk koneksi saraf baru sepanjang hidup, yang dipengaruhi oleh rangsangan intrinsik atau ekstrinsik, atau kapasitas neuron dan jaringan saraf di otak untuk mengubah koneksi dan perilaku mereka dalam menanggapi informasi baru, stimulasi sensorik, pengembangan, kerusakan atau disfungsi. Jones (dalam Kania dkk, 2017: 42) mengemukakan bahwa bentuk plastisitas sinaptik yang bergantung pada pengalaman, seperti seluler selama potensiasi sinaptik jangka panjang (LTP) dan depresi sinaptik jangka panjang (LTD), secara luas dianggap sebagai mekanisme seluler pembelajaran dan memori. LTP mencerminkan peningkatan kekuatan sinaptik dan membutuhkan aktivasi reseptor glutamat atau subtipe reseptor lainnya.

Menurut Sujana (2018:3-4) Neuroplastisitas secara umum dapat dibagi menjadi dua, yaitu neuroplastisitas struktural dan fungsional. Pertama, Neuroplastisitas struktural merupakan plastisitas sinaps yang merujuk pada perubahan pada kekuatan antar neuron (sinaps), titik pertemuan kimiawi atau elektrik antar sel-sel otak yang dapat meliputi banyak proses spesifik seperti perubahan jangka panjang pada jumlah reseptor untuk neurotransmitter tertentu, atau perubahan di mana beberapa protein disintesis lebih banyak di dalam sel. Sinaptogenesis merujuk pada pembentukan dan penyatuan sinaps atau kelompok sinaps ke dalam sirkuit saraf. Plastisitas struktural merupakan ciri neuron janin selama masa perkembangan otak dan disebut juga plastisitas masa perkembangan meliputi neurogenesis dan migrasi neuron. Migrasi neuron merupakan proses dimana neuron berpindah dari "tempat kelahirannya" di ventrikel janin atau daerah subventrikel menuju posisi akhir mereka di daerah korteks. Selama masa perkembangan, 
area otak menjadi terspesialisasi untuk tugas-tugas tertentu seperti memproses sinyal dari area sekitar melalui reseptor sensorik. Sebagai contoh pada area oksipital otak, lapisan keempat korteks mengalami hipertrofi untuk menerima sinyal dari jalur visual. Neuroplastisitas ini memiliki keistimewaan yaitu Neurogenesis. Neurogenesis adalah pembentukan neuron-neuron baru. Proses ini berlangsung terutama selama masa perkembangan otak. Sebaliknya, kematian neuron berlangsung disepanjang masa kehidupan baik itu akibat kerusakan otak atau karena kematian sel yang terprogram. Bentuk lain neuroplastisitas stuktural meliputi perubahan pada tingkat kepadatan substansia grisea atau alba yang dapat dilihat dengan MRI.

Kedua, Neuroplastisitas fungsional. Neuroplastisitas fungsional bergantung pada dua proses dasar yaitu belajar dan memori. Mereka mewakili plastisitas neural dan sinaptik jenis khusus, berdasarkan pada plastisitas sinaptik jenis tertentu, menyebabkan perubahan permanen pada efektivitas sinaptik. Selama proses belajar dan mengingat, perubahan permanen terjadi pada hubungan sinaptik antar neuron akibat penyesuaian struktural atau proses biokimia intraseluler. Neuroplastisitas ini memiliki tahapan perkembangan sinaps. Sinaps ini adalah pertemuan antar neuron yang membentuk satu kesatuan, ketika kita lahir kita memiliki sinaps dan terus bertambah. Bambang Iman Santoso menambahkan pada usia 2-3tahun, otak aktif membentuk sinapsis sampai 2 juta setiap detiknya. Sinaps ini adalah sambungan antara neuron dengan neuron lainnya didalam otak.

Terdapat tiga jenis plastisitas yang dapat dibedakan pada otak normal: experienceindependent, experience-expectant, dan experience-dependent. Plastisitas experienceindependent sebagian besar merupakan suatu proses perkembangan prenatal. Tidaklah praktis bagi genome untuk menspesifikasi konektivitas setiap koneksi pada fase perkembangan neuron. Namun, otak membentuk struktur kasar, di mana terdapat overproduksi neuron dan nantinya koneksi-koneksi akan dibentuk berdasarkan stimulus internal dan eksternal (Sujana, 2018: 10).

Plastisitas experience-expectant sebagian besar terjadi selama tahap pertumbuhan. Contoh yang bagus adalah perkembangan kolom dominan okular pada korteks visual primer. Wiesel dan Hubel (1963) menunjukkan, apabila salah satu mata anak kucing ditutup sejak lahir, mata yang terbuka akan memperluas teritorinya, yang menyebabkan penyusutan kolom pada mata yang tertutup. Jika mata yang tertutup pada akhirnya dibuka maka penglihatan akan terganggu (Sujana, 2018: 11).

Akhirnya, plastisitas experience-dependent merupakan proses merubah susunan neuron yang sudah ada. Kuncinya adalah bahwa perubahan sinaps merupakan cerminan dari modifikasi fenotipe dasar yang terbentuk pada masa perkembangan. Penting untuk diketahui bahwa pada plastisitas jenis ini terjadi penambahan maupun pemotongan sinaps namun pada regio otak yang berbeda (Sujana, 2018: 11).

Bambang Iman Santoso menambahkan bahwa prinsip neuroplastisitas ada 3 yaitu learning, unlearning dan relearning. Melatih neuroplastisitas ini dilakukan dengan cara learning untuk membuat patway baru. Patway adalah sambungan antara sinaps yang membentuk satu kesatuan. Sementara, unlearning artinya ingin merubah pola pikir sebelumnya, seperti memerintahkan "jangan melakukannya lagi" atau "jangan mempelajarinnya lagi". Kemudian, relearning ialah memperkuat patway yang ada agar tetap bisa terus dilakukan tindakan tersebut.

Kania dkk. (2017: 45-46) mengemukakan bahwa Plastisitas otak didefinisikan sebagai reorganisasi jalur saraf sebagai respons terhadap rangsangan eksternal, yang terutama dinyatakan dalam modulasi kepadatan dan kuantitas jalur saraf dengan perubahan dalam mode komunikasi sinaptik. Selain itu, perubahan morfologis terjadi pada neuron. Perubahan plastis pada sistem saraf adalah konsekuensi dari perkembangan alami dan kehidupan suatu organisme; namun, secara paradoks perubahan-perubahan ini juga dapat terjadi dari berbagai jenis kerusakan dan cedera, aktivitas berulang (pengalaman) dalam menanggapi rangsangan lingkungan, proses pembelajaran dan memori, atau kecanduan. Sistem saraf sangat rentan terhadap faktor-faktor ini selama tahap perkembangan; Namun, kapasitas ini dipertahankan di otak orang dewasa. Stimuli yang mengubah struktur saraf termasuk obat-obatan psikoaktif, diet, penyakit, stres, faktor pertumbuhan, agen anti-inflamasi, hormon seks, dan kerusakan otak organik. 
Ming dan Song (dalam Kania dkk, 2017: 46) mengemukakan bahwa perubahan perilaku dikaitkan dengan perubahan dalam organisasi dan / atau sifat-sifat otak, terutama oleh modifikasi atau penciptaan unsur-unsur baru, yang dapat menghasilkan jejak anatomis. Perubahanperubahan ini hadir, terutama, pada tingkat sinaps. Pemeriksaan terhadap perubahan ini sulit dilakukan karena bidang yang diminati akan selalu terlalu terbatas, relatif terhadap jumlah sinapsis yang sangat besar, yang bagi otak manusia terdiri dari 100 miliar sel saraf yang masingmasing dapat menghasilkan beberapa ribu sinapsis. Teknik pewarnaan neuron Golgi yang sederhana digunakan untuk memperkirakan perubahan jumlah sinapsis yang bergantung pada perubahan panjang dendritik atau kepadatan tulang belakang dendritik. Metode ini digunakan untuk mengidentifikasi perbedaan yang signifikan dalam jumlah sinapsis di wilayah otak hewan peliharaan, yang ditempatkan di lingkungan yang kaya atau miskin dalam rangsangan. Dalam lingkungan yang diperkaya, misalnya, di mana unsur perangsang, seperti roda berjalan, diperkenalkan, peningkatan dua hingga tiga kali lipat terjadi pada jumlah neuron hippocampal.

Neuroplastisitas sebagai multi-domain neurobiologis, kognitif, dan psikologis yang relevan dalam depresi dan gangguan terkait lainnya dari pengaruh negative, misalnya kecemasan (Price dan Duman, 2019: 1). Neuroplastisitas memiliki peran mengendalikan atau memilih apa yang di lakukan otak meliputi, memilih makanan, kebutuhan, keinginan, kecemasan, bahaya, dan lain-lain.

Pentingnya peranan neuroplastisitas dalam hidup manusia mendorong beberapa pihak untuk merancang sebuah video edukasi tentang hal tersebut. Video edukasi tersebut memiliki fungsi untuk memberitahukan masyarakat luas tentang ilmu neuroplastisitas. Menurut Turyati dkk., (2016: 5) mengemukakan bahwa Kemampuan video dalam memvisualisasikan materi efektif untuk membantu menyampaikan materi yang bersifat dinamis. Video edukasi mudah diingat karena seolah olah dialaminya sendiri. Penggunaan video edukasi sebagai media pembelajaran mampu memberi kejelasan pesan karena manusia melihat obyek belajar secara konkret. Selain itu, penggunaan media video edukasi dapat meningkatkan motivasi dan retensi (daya ingat dan daya serap) manusia.

\section{METODE PENELITIAN}

Metode penelitian yang digunakan adalah penelitian kualitatif. Penelitian kualitatif ini beracuan pada studi literatur, observasi, dan wawancara dengan narasumber. Adapun tujuan dari penelitian ini adalah untuk bisa melihat apakah video edukasi yang disampaikan melalui bentuk visual ini bisa diterima dan dimengerti keseluruhannya oleh masyarakat. Dari segi pemilihan tipografi, dari segi pemilihan ilustrasi, dan warna.

Menurut Moleong (2007: 6) metode kualitatif adalah jenis penelitian yang bermaksud untuk memahami fenomena tentang apa yang dialami oleh subjek penelitian misalnya perilaku, presepsi, motivasi, tindakan, dan lain-lain. Secara holistik dan dengan cara deskripsi dalam bentuk kata kata dan bahasa, pada suatu konteks khusus yang alamiah dan dengan memanfaatkan berbagai metode alamiah. Untuk mendapatkan data yang nantinya menjadi acuan penelitian antara lain melalui studi literatur, wawancara kepada narasumber dan observasi ke tempat-tempat tertentu. Tujuan dari dilakukannya penelitian ini yaitu diharapkan dapat menganalisis serta mendeskripsikan objek yang diteliti dengan cara metode kulitatif. Tujuan menggunakan metode penelitian kualitatif agar menerapkan teori teori dari data yang telah ada untuk melihat video edukasi dari segi tipografi, ilustrasi dan warna.

\section{HASIL DAN PEMBAHASAN}

Objek pembahasan dalam artikel ini akan berfokus pada video edukasi tentang visualisasi neuroplastisitas yang terdapat pada salah satu platform youtube dengan nama channel "Sentis". Channel tersebut memuat sejumlah informasi yang disampaikan melalui video. Channel tersebut terlihat dari isi videonya berkaitan tentang otak maupun kehidupan manusia. Channel tersebut dibuat untuk solusi psikologis dan inovatif untuk tantangan bisnis sehari-hari. Channel ini juga memiliki web yaitu www.sentis.com.au. 
Otak manusia memiliki perkembangan dan struktur tertentu. Otak manusia juga memiliki banyak keistimewaan, salah satunya neuroplastisitas. Neuroplastisitas ini adalah keistimewaan yang dimiliki otak karena meliputi neurogenesis, plastisitas sinaps, dan synaptogenesis. Kania dkk. (2017: 42) mengemukakan bahwa plastisitas otak atau neuroplastisitas adalah kapasitas yang melekat pada jaringan saraf dan berfungsi untuk membentuk koneksi atau sinapsis interneuronal baru (sinaptogenesis) atau mengganti yang tidak berguna, tidak berfungsi (degenerasi saraf) neuron di otak dengan neuron baru (neurogenesis). Plastisitas sinaptik adalah kemampuan untuk mengubah kekuatan sinaptik. Perubahan kekuatan termasuk neurotransmiter. Neuroplastisitas terdiri dari dasar neurokimia yang penting dalam pembelajaran dan memori.

Efek neuroplastisitas adalah menata ulang fungsi neuron untuk memungkinkan adaptasi dan perbaikan diri yang cepat, yang dapat diterjemahkan ke dalam proses pembelajaran dan memori di semua tingkat sistem saraf. Ini juga terdiri dari rangsangan intrinsik dari neuron dengan pengaruh pada penyimpanan informasi. Neuroplastisitas berperan untuk membentuk pola pikir, membentuk karakter, membentuk masa depan seseorang. Otak manusia dewasa dianggap sebagai sebuah struktur organ yang terbentuk selama masa perkembangan dan kemudian menjadi kaku saat dewasa. Perubahan pada otak yang diterima dahulu hanyalah sebatas pada proses belajar dan memori. Namun, faktanya otak ternyata mengalami perubahan yang berkelanjutan sepanjang masa hidup dan hal ini merupakan salah satu penemuan terpenting dalam ilmu neuroscience modern. Perubahan yang terjadi di otak ini dikenal dalam sebuah istilah umum, yaitu neuroplastisitas, yang meliputi neurogenesis, plastisitas sinaps, dan synaptogenesis (Chostandy dan Moheb dalam Andreas, 2013: 132-135).

Perancangan video edukasi tentang neuroplastisitas ini dibuat dengan menerapkan aspek elemen visual. Perancangan tersebut dibuat agar penonton bisa mengerti dan mengingatnya dengan mudah. Elemen visual menjadi sesuatu yang penting dalam pembuatan video tersebut. Dikarenakan dengan elemen visual penonton akan mudah menangkap dan mengerti serta tidak membosankan. Dari unsur elemen visual juga penonton menangkap informasi yang ingin disampaikan.

Video merupakan salah satu jenis media pembelajaran yang berbasis audio-visual yang berfungsi untuk merangsang indera pendengaran dan indera penglihatan (Turyati dkk., 2016: 258). Perancangan video edukasi ini diharapkan agar semua orang bisa mengetahui dan mengerti tentang neuroplastisitas. Adanya penelitian tentang kapasitas video sebagai media pembelajaran, membuat peneliti semakin terdorong untuk membuat video edukasi dengan tema neuroplastisitas. Hasil penelitian tersebut dapat dilihat sebagai berikut. Pertama, penelitian yang dilakukan oleh Iwan Permana Suwarna (2014) menunjukkan bahwa pembelajaran yang menggunakan media video memiliki daya dukung terhadap hasil belajar pada kategori baik dengan persentase $79 \%$. Penelitian Thomas Adi Tri Nugroho (2015) menunjukkan bahwa hasil belajar kelas eksperimen lebih besar daripada hasil belajar kelas kontrol. Hasil belajar kelas eksperimen adalah 80,00; dan hasil belajar kelas kontrol adalah 70,86. Penelitian Tabah Listiyanto (2015), menunjukkan bahwa pembelajaran dengan pemanfaatan video edukasi sebagai media pembelajaran mempengaruhi motivasi belajar sebesar 44,1\% (Turyati dkk., 2016: 258).

\section{Analisis Elemen Visual}

Analisis yang peneliti pakai adalah analisis media, yang membahas tentang analisis penggunaan tanda verbal dan tanda visual dalam media. Media yang digunakan adalah video edukasi yang bersumber di youtube channel Sentis. Video edukasi mudah diingat karena seolah olah dialaminya sendiri. Penggunaan video edukasi sebagai media pembelajaran mampu memberi kejelasan pesan karena manusia melihat obyek belajar secara konkret. Selain itu, penggunaan media video edukasi dapat meningkatkan motivasi dan retensi (daya ingat dan daya serap) manusia (Turyati dkk., 2016: 5). 


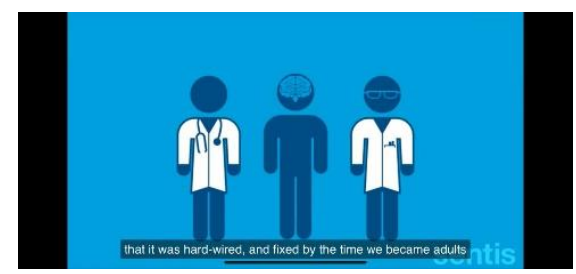

Gambar 2 Penampilan karakter video "neuroplastisitas"

Gambar diatas ialah salah satu isi dari video edukasi neuroplastisitas, menggunakan jenis font Arial, salah satu jenis font Sans Serif. Jenis font ini menggambarkan sesuatu yang universal, bersih, modern, objektif, dan stabil. Penggunakan font ini dilakukan untuk menggambarkan sesuatu yang global, yang mana dapat diterima oleh segala golongan. Tinarbuko (dalam Umari, 2019: 19) mengemukakan bahwa keberadaan tipografi dalam rancangan karya desain komunikasi visual sangat penting, karena mampu menguatkan isi pesan verbal karya desain komunikasi visual dengan memperhatikan perencanaan dan pemilihan tipografi yang tepat, baik ukuran, warna dan bentuk.

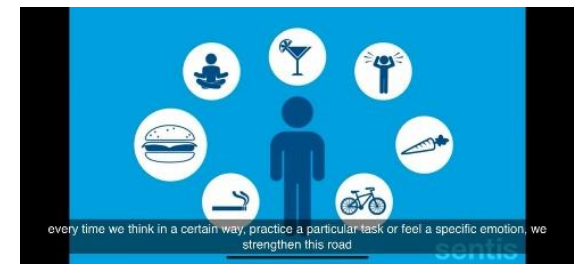

Gambar 3 Komposisi video edukasi "Neuroplastisitas"

Ilustrasi di video edukasi tersebut menggambarkan makna yang ingin disampaikan, sudah sesuai dengan penyampaian ilustrasi yang baik. Seperti menjelaskan perubahan patway. Cara kerja neuroplastisitas di video tersebut juga sudah sangat jelas dan bisa dimengerti apa yang ingin disampaikan. Supriyono (dalam Umari, 2019: 17) mengemukakan bahwa ilustrasi secara umum adalah gambar atau foto yang bertujuan menjelaskan teks dan sekaligus menciptakan daya tarik.

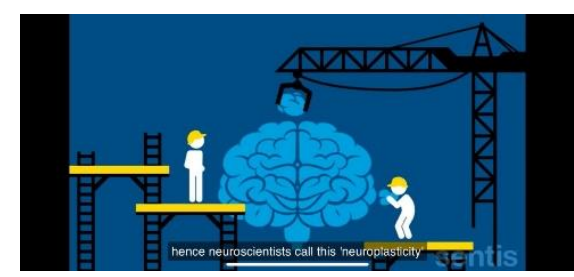

Gambar 4 Ilustrasi video edukasi "Neuroplastisitas"

Video edukasi ini menggunakan perpaduan warna dingin dengan warna hangat yang sangat baik. Penggunaan warna hangat membuat ilustrasi terkesan lebih hidup atau nyata. Wibowo (dalam Umari, 2019: 16) mengemukakan bahwa sifat warna dikelompokkan menjadi 2 yaitu: 1) Warna dingin adalah warna-warna yang mengarah pada warna biru dan hijau, warna tersebut memiliki kesan lembut, teduh dan tenang, dan 2) Warna panas adalah warna-warna yang mengarah pada warna kuning dan jingga, warna tersebut memiliki kesan panas mencolok, semangat, bijaksana dan dinamis.

Dari tipografi, warna, ilustrasi, bisa disimpulkan bahwa video tersebut terbilang layak, mulai dari pemilihan tipografinya yang global dan bisa di terima oleh semua masyakarat (general), pemaduan warnanya sangat nyaman dilihat, hingga ilustrasi yang dapat merepresentasikan isi pesan dengan baik. 


\section{SIMPULAN}

Pembahasan di atas menjelaskan bahwa elemen visual harus dapat merepresentasikan konsep/ide utama yang dibangun oleh perancang video. Selain itu, ilustrasi yang sarat dengan keseharian memberi poin plus video tersebut. Elemen visual yang digunakan pada video, mulai dari warna, tipografi, dan ilustrasi yang dipilih sesuai dengan kapasitas audiens yang ditargetkan.

\section{DAFTAR PUSTAKA}

Andreas, H. (2016). Neuroplastisitas. [Online]. Diakses dari https://edoc.pub/neuroplastisitaspdf-free.html.

Kania, B.F., Zieba, D., \& Fortuna, D.W. (2017). Introduction to neural plasticity mechanism. Journal of Behavioral and Brain Science, 7(01), 41-49. https://doi.org/10.4236/jbbs.2017.72005.

Kembaren (2018). Neuroplastisitas otak. [Online]. Diakses dari http://yankes.kemkes.go.id/readneuroplastisitas-otak-4597.html.

Moleong, Lexy J. (2007). Metodologi Penelitian Kualitatif, Penerbit PT Remaja Rosdakarya Offset, Bandung.

Price, R.B., \& Duman, R. (2019). Neuroplasticity in cognitive and psychological mechanisms of depression: an integrative model. Mol Psychiatry, 25, 530-543. https://doi.org/10.1038/s41380-019-0615-x.

Sujana, I.B.G. (2018). Efek anesthesia umum terhadap neuroplastisitas pasien pediatrik. (Skripsi). Sekolah Sarjana, Universitas Udayana, Denpasar.

Turyati, Muchatarom, M., \& Winarno. (2016). Pengaruh penggunaan media video edukasi terhadap hasil belajar pkn siswa kelas vii smp negeri 2 gondangrejo. PKn Progresif, 11(1), 257-267. https://jurnal.fkip.uns.ac.id/index.php/progresif/article/view/9724.

Umari, P. R. L. (2019). Perancangan media infografis kewirausahaan sosial sebagai solusi dari permasalahan sosial. (Skripsi). Sekolah Sarjana, Universitas Indraprasta Pgri, Jakarta.

Wattimena, R.A.A (2015). Otak, neuro plastisitas dan hidup kita. [Online]. Diakses dari https://rumahfilsafat.com/2015/11/12/otak-neuroplastisitas-dan-hidup-kita/. 